\title{
PENGGUNAAN SENSOR PASSIVE INFRARED RECEIVER (PIR) UNTUK MENDETEKSI GERAK BERBASIS SHORT MESSAGE SERVICE GATEWAY
}

\author{
Rozali Toyib $^{1}$, Iwan Bustami ${ }^{2}$, Dedy Abdullah ${ }^{3}$, Onsardi $^{4}$ \\ ${ }^{1,2,3}$ Teknik Informatika, Fakultas Teknik, Universitas Muhammadiyah Bengkulu \\ ${ }^{4}$ Sistem Informasi, Fakultas Teknik, Universitas Muhammadiyah Bengkulu \\ Jl. Bali Po. Box, 118 Kota Bengkulu 38119 Indonesia \\ ${ }^{1}$ rozalitoyib@umb.ac.id \\ ${ }^{2}$ iwanbustamilgmail.com \\ ${ }^{3}$ dedy_abdullah@umb.ac.id \\ ${ }^{4}$ onsardieumb.ac.id
}

\begin{abstract}
Abstrak: Pada umumnya aktifitas orang-orang yang tinggal di perkotaan besar begitu banyak dan padat sehingga menjadikannya jarang berada di rumah, hampir sebagai besar waktu mereka dihabiskan di tempat kerja karena tuntutan pekerjaan karena hal inilah menyebabkan kekuatiran bagi mereka dikala meninggalkan rumah walaupun sebenarnya mereka telah memberi pengaman berupa alat konvensional dalam ini adalah berupa gembok atau bagi yanng tinggal di komplek bisa menyewa satpam, tetapi ini tidak menjadi jaminan karena adakalah terjadi kelalaian dan dimungkin di kala malam hari mereka ketiduran karena kecapean hal ini rawan terjadinya tindak kejahatan yang terjadi pada lingkungan rumah. Salah satu cara pemanfaatan teknologi di bidang ini adalah penggunaan sensor Passive Infrared Receiver (PIR). Sensor Passive Infrared Receiver (PIR) merupakan sebuah sensor yang biasa digunakan untuk mendeteksi keberadaan manusia. Proses kerja sensor ini dilakukan dengan mendeteksi adanya radiasi panas tubuh manusia yang dapat diubah menjadi tegangan,Sensor Passive Infrared Receiver (PIR) sangat tepat digunakan untuk membuat suatu sistem pemantauan ruang jarak jauh yang dapat dimanfaatkan pemilik rumah tanpa harus takut meninggalkan rumahnya. Berdasarkan hasil pengujia : Sensitifitas darisensor Passive Infrared Receiver (PIR) mengirim data hasil pengamatan kepaadmikrokontrolertelah terukur dengan delay rata-rata SMS 15.1 detik dan Pada umumnya sensor Passive Infrared Receiver (PIR) ini memiliki jangkauan pembacaan efektif hingga 5 meter, dan sensor ini sangat efektif digunakan sebagai human detector.
\end{abstract}

Kata Kunci: kejahatan, sensor, passive infrared receiver, human detector.

Abstract: In general, the activities of people living in large cities are so many and dense that they are rarely at home, almost as much as they spend in the workplace because of work demands because this causes them to worry when leaving home even though they have actually provided safety in the form of conventional tools in this is a padlock or for those who live in a complex can hire security guards, but this is not a guarantee because there is negligence and is possible at night when they fall asleep due to exhaustion this is prone to crime that occurs in the home environment. One way to use technology in this field is the use of Passive Infrared Receiver (PIR) sensors. Passive Infrared Receiver (PIR) sensor is a sensor commonly used to detect human presence. The sensor work process is carried out by detecting the radiation of human body heat that can be transformed into a voltage, the Passive Infrared Receiver (PIR) sensor is very suitable to be used to create a remote space monitoring system that can be used by homeowners without having to fear leaving their homes. Based on the results of testing: Sensitivity from the Passive Infrared Receiver (PIR) sensor sends data on the monitoring of the microcontroller after being measured with an average delay of 15.1 seconds and in general the Passive Infrared Receiver (PIR) sensor has an effective reading range of up to 5 meters, and the sensor is very effective used as a human detector. 
Jurnal Pseudocode, Volume V Nomor 2, September 2018, ISSN 2355-5920, e-ISSN 2655-1845 www.ejournal.unib.ac.id/index.php/pseudocode

Keywords: Crime, sensor, Passive Infrared Receiver, human detector.

\section{PENDAHULUAN}

Pada umumnya aktifitas orang-orang yang tinggal di perkotaan besar begitu banyak dan padat sehingga menjadikannya jarang berada di rumah, hampir sebagai besar waktu mereka dihabiskan di tempat kerja karena tuntutan pekerjaan karena hal inilah menyebabkan kekuatiran bagi mereka dikala meninggalkan rumah walaupun sebenarnya mereka telah memberi pengaman berupa alat konvensional dalam ini adalah berupa gembok atau bagi yanng tinggal di komplek bisa menyewa satpam, tetapi ini tidak menjadi jaminan karena adakalah terjadi kelalaian dan dimungkin di kala malam hari mereka ketiduran karena kecapean hal ini rawan terjadinya tindak kejahatan yang terjadi pada lingkungan rumah.

Akhir-akhir ini semakin sering terjadi, angka kriminalitas pun semakin meningkat, para pencuri biasanya menarget rumah-rumah kosong atau yang ditinggal oleh penghuninya dan biasanya modusnya dengan mencongkel atau merusak pintu. membantu memperingati atau memberi tahu jika ada yang ingin berniat jahat ataupun memasuki rumah anda dalam keadaan anda tidak ada di tempat atau rumah dalam keadaan kosong maupun tidak, maka untuk itu perlu dibuat alat bisa bereaksi dan berkerja secara otomatis serta memberitahu pengguna apabila ada terdeteksi panas tubuh manusia dan sinar inframerah pasif yang di keluarkan dari tubuh manusia atau indikator pencuri.

Melihat sering terjadinya tindak kejahatan yang dilakukan pencuri dengan sasaran rumahrumah penduduk baik yang sedang ditinggal oleh pemiliknya maupun tidak, membuat orang resah apabila hendak meninggalkan rumahnya tanpa berpenghuni. Kebutuhan akan suatu sistem yang memberikan keamanaan itu sangat diminati banyak orang. Untuk mengatasi masalah pencuri memang sudah ada, yaitu dengan memasang suatu sistem keamanan rumah dengan menggunakan berbagai macam bentuk, diantaranya ada yang menggunakan kamera pemantau dan ada pula yang menggunakan jenis pengaman yang lebih canggih lagi seperti automatic door yang hanya dapat dibuka dengan kode atau password. Salah satu cara pemanfaatan teknologi lain di bidang ini adalah penggunaan sensor PIR. Sensor PIR merupakan sebuah sensor yang biasa digunakan untuk mendeteksi keberadaan manusia. Proses kerja sensor ini dilakukan dengan mendeteksi adanya radiasi panas tubuh manusia yang dapat diubah menjadi tegangan. Sensor PIR sangat tepat digunakan untuk membuat suatu sistem pemantauan ruang jarak jauh yang dapat dimanfaatkan pemilik rumah tanpa harus takut meninggalkan rumahnya [1].

\section{LANDASAN TEORI}

\section{A. Mikrokontroler}

Mikrokontroler popular yang pertama dibuat oleh Intel pada tahun 1976, yaitu mikrokontroler 8-bit Intel 8748. Mikrokontroler tersebut adalah bagian dari keluarga mikrokontroler MCS-48. Sebelumnya, Texas instruments telah memasarkan mikrokontroler 4- bit pertama yaitu TMS 1000 pada tahun 1974 (Andrianto 2008:2). Mikrokontroler adalah sebuah sistem komputer lengkap dalam satu serpih (chip). Mikrokontroler lebih dari sekedar sebuah mikroprosesor karena sudah terdapat atau berisikan ROM (Read-Only Memory), RAM (Read-Write Memory), beberapa bandar masukan maupun keluaran, dan beberapa peripheral seperti pencacah/pewaktu, ADC 
Jurnal Pseudocode, Volume VI Nomor 2, September 2019, ISSN 2355-5920, e-ISSN 2655-1845 www.ejournal.unib.ac.id/index.php/pseudocode

(Analog to Digital converter), DAC (Digital to Analog converter) dan serial komunikasi [2].

B. Sensor PIR (Passive Infrared Receiver)

Sensor PIR (Passive Infrared Received) adalah sensor yang digunakan untuk mendeteksi adanya pancaran sinar infra merah. Sensor PIR (Passive Infrared Received) bersifat pasif, artinya sensor ini tidak memancarkan sinar infra merah tetapi hanya menerima radiasi sinar infra merah dari luar.

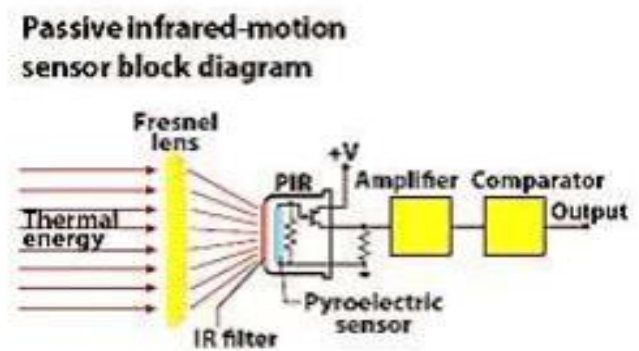

Gambar 1. Sensor PIR (Passive Infrared Receiver)

Sensor ini biasanya digunakan dalam perancangan detektor gerakan berbasis PIR (Passive Infrared Received). Karena semua benda memancarkan energi radiasi, sebuah gerakan akan terdeteksi ketika sumber infra merah dengan suhu tertentu (misal: manusia) melewati sumber infra merah yang lain dengan suhu yang berbeda (misal: dinding), maka sensor akan membandingkan pancaran infra merah yang diterima setiap satuan waktu, sehingga jika ada pergerakan maka akan terjadi perubahan pembacaan pada sensor.

Sensor PIR (passive infrared receiver) terdiri dari beberapa bagian yaitu: 1. Lensa Fresnel 2. Penyaring Infra Merah 3. Sensor Pyroelektrik 4. Penguat Amplifer 5. Komparator Gambar 2. Arah jangkauan gelombang sensor PIR Seperti yang ditunjukkan pada Gambar 2, ketika ada sebuah objek melewati sensor, pancaran radiasi infra merah pasif yang dihasilkan akan dihasilkan akan dideteksi oleh sensor. Energi panas yang dibawa oleh sinar infra merah pasif ini menyebabkan aktifnya material pyroelektric di dalam sensor yang kemudian menghasilkan arus listrik [3].

Passive Infrared Receiver merupakan sebuah sensor berbasis infrared. Akan tetapi, tidak seperti sensor infrared kebanyakan yang terdiri dari IR LED dan fototransistor. PIR tidak memancarkan apapun seperti IR LED. Sesuai dengan namanya'Passive', sensor ini hanya merespon energi dari pancaran sinar inframerah pasif yang dimiliki oleh setiap objek bergerak yang terdeteksi olehnya . Pengertian dari Infra Red atau Infra merah adalah gelombang elektromagnetik yang tidak dapat ditangkap mata, dengan panjang gelombang antara 0,78 m sampai $1 \mathrm{~mm}$ [4].

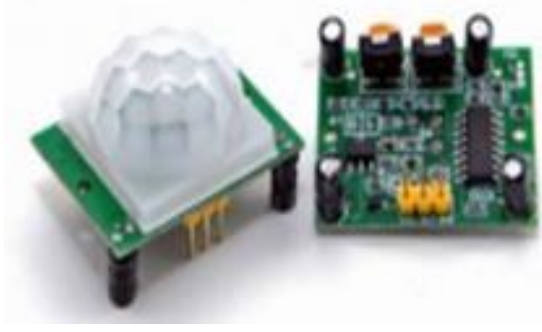

Gambar 2. Sensor PIR (Passive Infrared Receiver)

C. Buzzer

Buzzer adalah suatu alat yang dapat mengubah sinyal listrik menjadi sinyal suara. Pada umumnya buzzer digunakan untuk alarm, karena penggunaannya cukup mudah yaitu dengan memberikan tegangan input maka buzzer akan mengeluarkan bunyi. Frekuensi suara yang di keluarkan oleh buzzer yaitu antara 1-5 KHz [5].
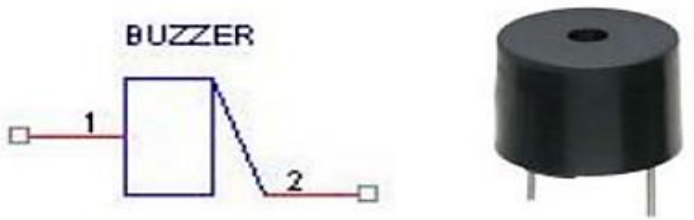

Gambar 3. Simbul dan Bentuk Buzzer

Alarm berfungsi untuk memberitahukan jika terjadi suatu kejadian tidak sesuai dengan yang diinginkan. Alarm yang akan digunakan pada alat 
Jurnal Pseudocode, Volume V Nomor 2, September 2018, ISSN 2355-5920, e-ISSN 2655-1845 www.ejournal.unib.ac.id/index.php/pseudocode

ini adalah alarm DC (buzzer). Gambar di bawah ini merupakan gambar rangkaian driver penguat alarm [6].

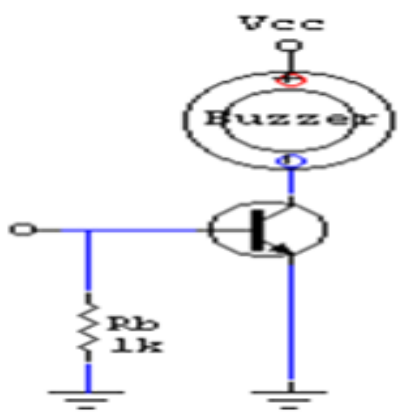

Gambar 4. Rangkaian Penguat Alarm

\section{Short Message Service (SMS)}

Istilah GateWay dapat diartikan sebagai gerbang, namun pada dunia komputer gatway dapat diartikan sebagai jembatan penghubungantara satu sistem dengan sistem yang lain, sehingga dapat terjadi suatu pertukaan data antara sistem tersebut, dengan demikian SMS Gateway dapat diartikan sebagai suatu penghubunguntuk lalu lintas dat-data SMS, baik yang dikirm maupun yang diterima [7].

SMS Gateway adalah sebuah perangkat yang menawarkan layanan transit SMS, mentransformasikan pesan ke jaringan selular dari media lain, atau sebaliknya, sehingga memungkinkan pengiriman atau penerimaan pesan SMS dengan atau tanpa menggunakan ponsel. Sebagaimana penjelasan diatas, SMS Gateway dapat terhubung ke media lain seperti perangkat SMSC dan server milik Content Provider melalui link IP untuk memproses suatu layanan SMS. Sebuah sistem SMS Gateway, umumnya terdiri komponen hardware (serverl komputer yang dilengkapi dengan perangkat jaringan) dan software (Aplikasi yang digunakan untuk pengolahan pesan). Dan untuk sebuah sistem yang besar umumnya menggunakan database untuk penyimpanan data [8].

\section{E. AT Command}

Perintah AT (Hayes AT Command) digunakan untuk berkomunikasi dengan terminal (modem) melalui gerbang serial pada komputer. Dengan penggunaan perintah AT, dapat diketahui atau dibaca kondisi dari terminal, seperti mengetahui kondisi sinyal, kondisi baterai, mengirim pesan, membaca pesan, menambah item pada daftar telepon, dan sebagainya. Pada Tabel 1 diperlihatkan beberapa jenis perintah AT yang berhubungan dengan penanganan pesan-pesan SMS.

Komunikasi data antara telepon seluler dengan peripheral lain seperti mikrokontroler dilakukan secara serial menggunakan perintah-perintah AT (Hayes AT Command), dengan mengirimkan telepon seluler untuk melakukan apa yang diperintahkan. Tabel berikut beberapa pereintahperintah AT yang digunakan untuk mengirim SMS [9].

Tabel 1. AT Command pada SMS

\begin{tabular}{|l|l|}
\hline Perintah & \multicolumn{1}{|c|}{ Fungsi } \\
\hline AT+CMGC & Mengirim sebuah perintah SMS \\
\hline AT+CMGD & Menghapus sebuah SMS \\
\hline AT+CMGF & Memori \\
\hline AT+CMGR & SMS Format \\
\hline AT+CMGS & Membaca dalam sebuah SMS \\
\hline AT+CSCA & $\begin{array}{l}\text { Mengirim sebuah SMS Alamat } \\
\text { dari pusat SMS servis }\end{array}$ \\
\hline AT+CMGL & Daftar SMS yang terdapat di HP \\
\hline AT+CSCA & $\begin{array}{l}\text { Alamat dari sebuah SMS Service } \\
\text { Center }\end{array}$ \\
\hline AT+CMNI & $\begin{array}{l}\text { Menampilkan pesan yang baru } \\
\text { masuk }\end{array}$ \\
\hline
\end{tabular}

F. Pengertian Dan Perbedaan jaringan CDMA Dan GSM

a. CDMA (Code Division Multple Access)

CDMA adalah teknik akses jamak yang menggunakan kode tertentu untuk membedakan 
Jurnal Pseudocode, Volume VI Nomor 2, September 2019, ISSN 2355-5920, e-ISSN 2655-1845 www.ejournal.unib.ac.id/index.php/pseudocode

user yang satu dengan yang lainnya. Teknologi ini pertama kali dikeluarkan

Telecommunication Industry Association, dengan adanya institusi sebagai motor penge mbangnya. CDMA adalah sebuah bentuk pemultipleksan (bukan sebuah skema pemodulasian) dan sebuah metode akses secara bersama yang membagi kanal tidak berdasarkan waktu (seperti pada TDMA) atau frekuensi (seperti pada FDMA), namun dengan cara mengkodekan data dengan sebuah kode khusus yang diasosiasikan dengan tiap kanal yang ada dan menggunakan sifat-sifat interferensi konstruktif dari kode kode khusus itu untuk melak ukan pemultipleksan.

CDMA menggunakan teknologi spreadspectrum untuk mengedarkan sinyal informasi yang melalui bandwidth yang lebar (1.25 MHz). CDMA membawa manfaat yang besar dan berada diatas teknologi serupa yang lain untuk saat ini. CDMA menawarkan kapasitas jaringan yang terbesar untuk melayani lebih banyak pelanggan dengan biaya infrastrukstur yang sama. CDMA menawarkan kecepatan transmisi data paling tinggi diantara yang lain.

\section{b. GSM (Global System for Mobile Communication)}

GSM itu singkatan dari Global System for Mobile Communication yang mulai diproduksi di era 1980-an. GSM beroperasi pada $900-1800 \mathrm{MHz}$ di Eropa dan India,sedangkan di AS sekitar 1900 MHz. Pengguna GSM menggunakan kartu SIM untuk bisa terhubung ke penyedia layanan. Kartu SIM adalah memori removable kecil yang dapat menampung semua data dan nomor identifikasi satu kebutuhan untuk mengakses layanan operator tertentu nirkabel [10].

\section{G. Pendeteksi Gerak}

a. Pendeteksi

Pendeteksi atau yang sering disebut Deteksi adalah Usaha menemukan dan menentukan keberadaan, anggapan, atau kenyataan, deteksi ini usaha untuk melacak sesuatu hal atau benda hidup maupun mati untuk diketahui kebenarannya.

b. Gerak

Gerak adalah suatu perubahan tempat kedudukan pada suatu benda dari titik keseimbangan awal. Sebuah benda dikatakan bergerak jika benda itu berpindah kedudukan terhadap benda lain baik perubahan kedudukan yang menjauhi maupun yang mendekat [11].

\section{H. Alarm}

Alarm dapat didefenisikan sebagai bunyi atau peringatan atau pemberitahuan, dalam istilah jaringan, alarm dapat juga didefenisikan sebagai pesan berisi pemberitahuan ketika terjadi penurunan atau kegagalan dalam penyampaian sinyal komunikasi data ataupun ada peralatan yang mengalami kerusakan (penurunan kinerja), pesan ini digunakan untuk memperingatkan operator atau administrator menganai adanya masalah (bahaya) pada jaringan. Alarm memberikan tanda berupa sinyal, bunyi, ataupun sinar. Sedangkan fungsi alarm memberitahukan apabila terjadi bahaya dan kerusakan ataupun kejadian yang tidak diinginkan pada jaringan melalui sinyal sehingga memberi peringatan secara jelas agar dapat di antisipasi [12]. 
Jurnal Pseudocode, Volume V Nomor 2, September 2018, ISSN 2355-5920, e-ISSN 2655-1845 www.ejournal.unib.ac.id/index.php/pseudocode

III. Metode PenElitian

A. Flowchart Alat Pendeteksi Gerak

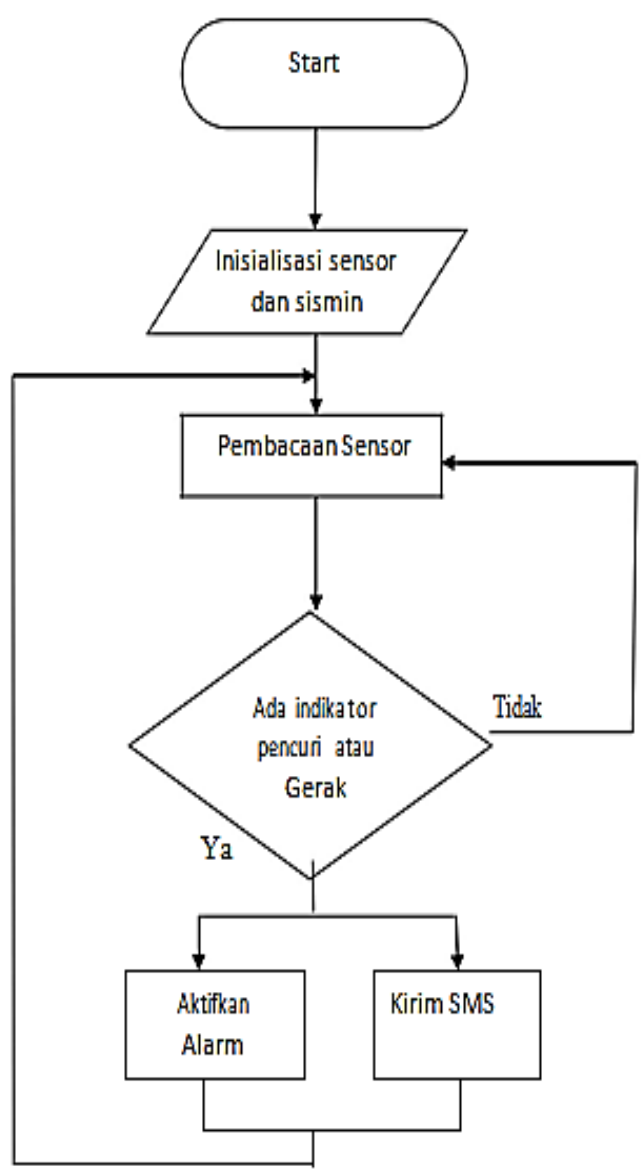

Gambar 5. Flowchart Pendeteksi Gerak

\section{B. Diagram Blok Kerja Alat}

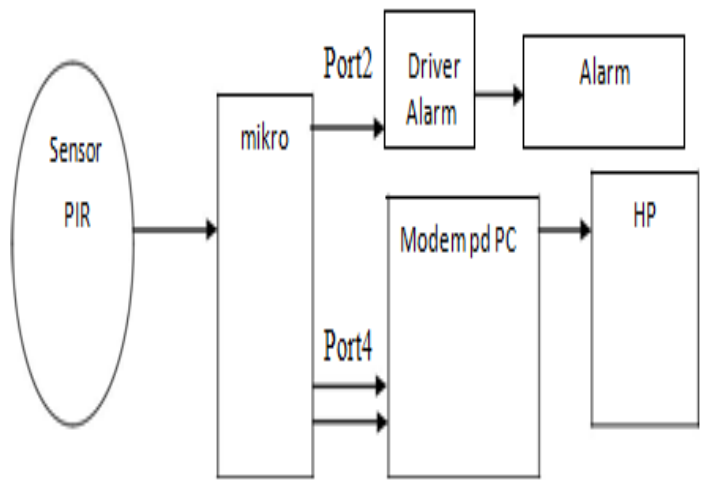

Gambar 6. Blok Diagram Kerja Alat

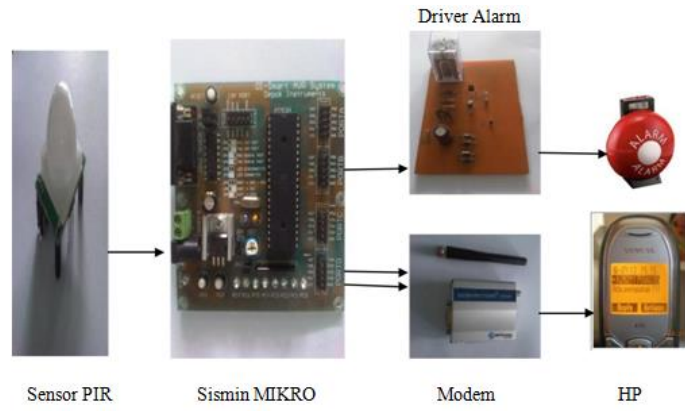

Gambar 7. Pengaturan Proses Alat.

Sensor ini hanya untuk mendeteksi panas tubuh manusia, apabila ada manusia mendekati sensor tersebet paling jauh jarak 3 Meter, maka sensor oti akan mendeteksi adanya suhu panas manusia, lalu mengirim sinyal ke mikro untuk diproses, pada posisi ini menjadi indikator bagi mikro untuk:

1. Memberi sinyal pada Port2 untuk mengaktifkan saklar dan Alarm.

2. Mengirim perintah ke Modem melalui port4 mengirim perintah mengirim SMS ke Handpone. Program SMS dan Alarm ini telah di atur dalam mikrokontroler.

\section{Perancangan pembuatan dan penempatan Alat}

1. Pembuatan Alat

Sensor ini hanya untuk mendeteksi panas tubuh manusia, apabila ada manusia mendekati sensor tersebet paling jauh jarak 3 Meter, maka sensor oti akan mendeteksi adanya suhu panas manusia, lalu mengirim sinyal ke mikro untuk diproses, pada posisi ini menjadi indikator bagi mikro untuk memproses untuk mengaktifkan Alarm dan mengirim SMS Otomatis, di dalam mikrokontroler ini telah ditanam suatu program untuk memproses dan mengirim sinyal untuk mengaktifkan alarm dan pengiriman SMS. 
Jurnal Pseudocode, Volume VI Nomor 2, September 2019, ISSN 2355-5920, e-ISSN 2655-1845 www.ejournal.unib.ac.id/index.php/pseudocode

2. Penempatan Alat

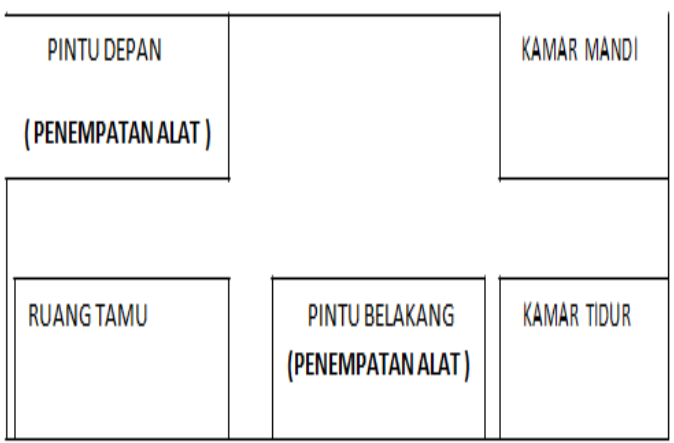

Gambar 8. Sketsa Penempatan Alat

Penempatan Alarm diletakkan pada Pintu rumah karena menjadi pusat jalan keluar masuk rumah. Penempatan ini akan sangat menguntungkan, karena biasanya pencuri sering kali merusak pintu rumah disaat mereka ingin melakukan niat jahat mereka yang merugikan orang lain, waktu mereka melawati pintu maka disaat itulah alat akan berkerja dan mendeteksi suhu panas dari tubuh manusia yang mendekati area Sensor tersebut, setelah terdeteksi maka sismin dari Sensor akan mengirim sinyal ke Mikro untuk mengaktifkan Alarm dan Pengiriman SMS otomatis.

\section{HASIL DAN PEMBAHASAN}

\section{A. Hasil}

\subsection{Bagian-bagian Alat}

Pada Gambar - Gambar di bawah ini adalah bagian - bagian dari alat yang digunakan untuk merancang alat pendeteksi gerak adalah:

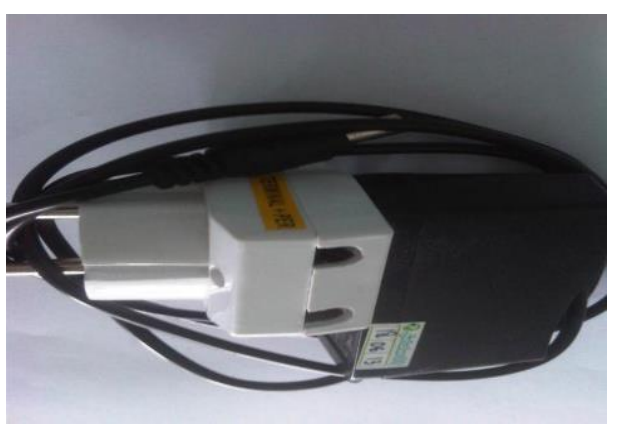

Gambar 9. Kabel serial (data) untuk menghubungkan modem ke mikro

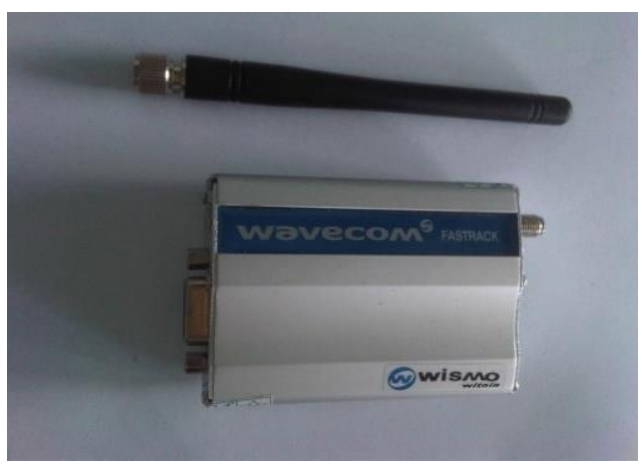

Gambar 10. Modem Wavecom Fastrack GSM untuk pengiriman SMS

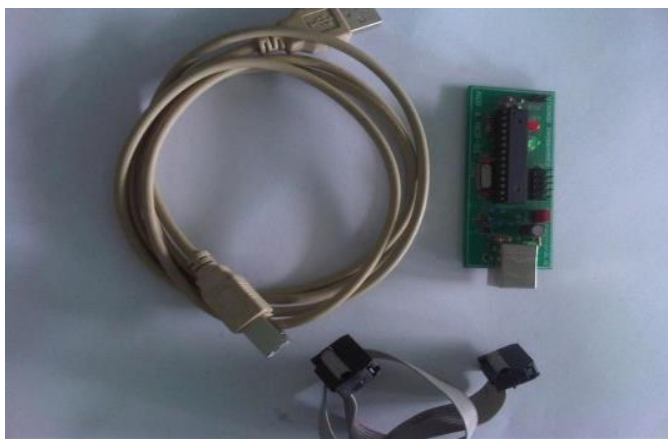

Gambar 11. Downloader (Alat yang digunakan untuk menanam program dari Komputer Mikro)

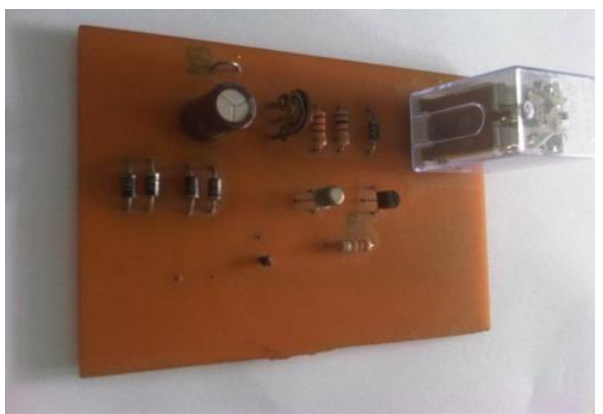

Gambar 12. Driver yang digunakan untuk menyambungkan ke alarm

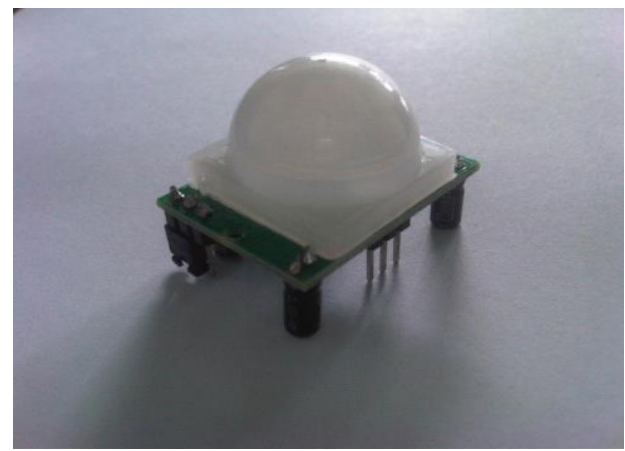

Gambar 13. Sensor PIR yang digunakan untuk mendeteksi gerakan manusia. 
Jurnal Pseudocode, Volume V Nomor 2, September 2018, ISSN 2355-5920, e-ISSN 2655-1845 www.ejournal.unib.ac.id/index.php/pseudocode

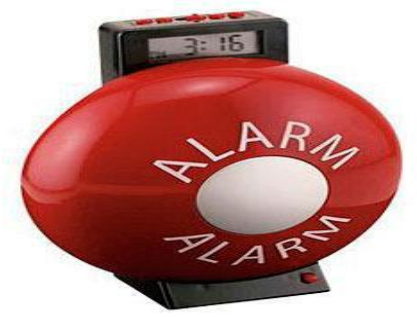

Gambar 14. Alarm yang dipakai untuk memberitahukan melalui suara apa bila ada penyusup

\subsection{Proses Perangkaian/Penggabungan}

Tampilan Alat ini adalah bagian - bagian alat yang anda lihat di atas telah dirangkain menjadi satu bagian supaya bisa berfungsi seperti apa yang terlihat digambar di bawah ini.

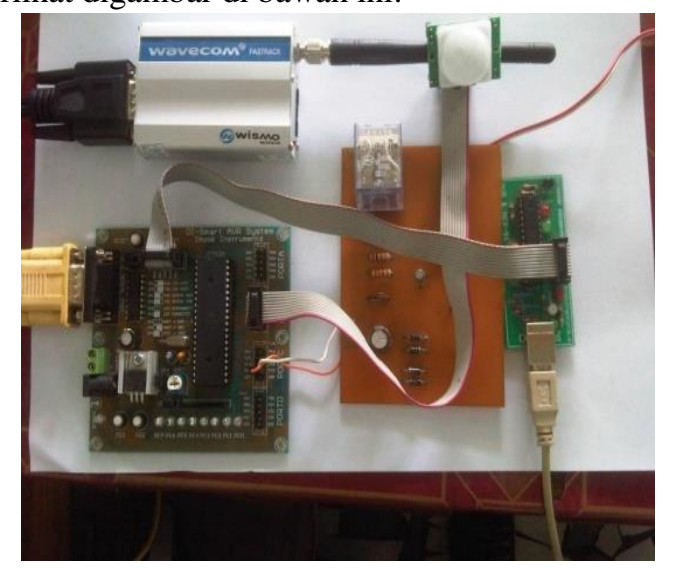

Gambar 15. Gambar Rangkaian Pendeteksi Gerak Berbasis

Short Messag Service Gateway dengan menggunakan Sensor Passive Infrared

Downloader dihubungkan dengan PORT ISP sistem minimum, Sensor PIR dihubungkan dengan PORTB sistem minimum, Driver Alarm dihubungkan dengan PORTC sistem minimum, Modem dihubungkan dengan PORTD sistem minimum melalui kabel serial (kabel data), Sistem minimum dan Modem diaktifkan dengan power suplay.

Downloader berguna untuk memasukan program yang telah dibuat di komputer menggunakan Codevision AVR ke dalam sistem minimum. Program ini mengontrol proses pembacaan sensor, pengaktifan alarm dan pengiriman sms. Sensor PIR berfungsi untuk mendeteksi adanya gerakan oleh manusia, apabila sensor mendeteksi gerakan, maka sensor PIR akan mengirimkan data High (1) ke PORTB sistem minimum. Oleh program yang telah ditanam ke dalam sistem minimum, data ini dianalisis untuk selanjutnya mengirimkan perintah mengaktifkan alarm yang dihubungkan di PORTC dan juga memerintah modem untuk mengirimkan SMS. Modem ini dihubungkan dengan PORTD sistem minimum yaitu pada PIN RXD (penerima) dan TXD (pengirim).

Driver alarm mendapat data High dari sistem minimum sehingga mengaktifkan relay yang terhubung ke rangkaian alarm, sehingga alarm akan berbunyi, alarm akan berbunyi dengan interval sekitar 3 detik setiap kali sensor mendeteksi gerakan.

Modem mendapat data serial perintah pengiriman sms yaitu menggunakan $A T$ COMMAND untuk pengiriman sms, sehingga setiap sensor mendeteksi gerakan maka modem akan mengirimkan SMS peringatan. Pada saat sensor tidak mendeteksi gerakan, maka baik alarm maupun modem tidak diaktifkan. Sensor PIR dan Driver Alarm mendapat supplay energi dari sistem yaitu sebesar $5 \mathrm{v}$, sedangkan sistem minimum dan modem mendapat daya dari power suplay dengan output 7,5 volt dan arus $1 \mathrm{~A}$.

Sensor PIR ini bekerja dengan menangkap energi panas yang dihasilkan dari pancaran sinar inframerah pasif yang dimiliki setiap benda dengan suhu benda diatas nol mutlak. Seperti tubuh manusia yang memiliki suhu tubuh kira-kira 32 derajat celcius, yang merupakan suhu panas yang khas yang terdapat pada lingkungan. Pancaran sinar inframerah inilah yang kemudian ditangkap oleh Pyroelectric sensor yang merupakan inti dari sensor PIR ini sehingga 
Jurnal Pseudocode, Volume VI Nomor 2, September 2019, ISSN 2355-5920, e-ISSN 2655-1845 www.ejournal.unib.ac.id/index.php/pseudocode

menyebabkan Pyroelectic sensor yang terdiri dari galium nitrida, caesium nitrat dan litium tantalate menghasilkan arus listrik. Mengapa bisa menghasilkan arus listrik, Hal ini dikarenakan pancaran sinar inframerah pasif ini membawa energi panas ketika seseorang berjalan melewati sensor, sensor akan menangkap pancaran sinar inframerah pasif yang dipancarkan oleh tubuh manusia yang memiliki suhu yang berbeda dari lingkungan sehingga menyebabkan material pyroelectric bereaksi menghasilkan arus listrik karena adanya energi panas yang dibawa oleh sinar inframerah pasif tersebut.

Ketika manusia itu melakukan gerakan, maka tubuh manusia itu akan menghasilkam pancaran sinar inframerah pasif dengan panjang gelombang yang bervariasi sehingga menghasilkan panas berbeda yang menyebabkan sensor merespon dengan cara menghasilkan arus pada material Pyroelectricnya dengan besaran yang berbeda beda maka alarm akan berbunyi dan manajemen pesan sms baik untuk pengiriman, pengaturan, antrian SMS, penerimaan SMS.

Saat mengirim pesan dari handphone, pesan tersebut dikirim ke SMSC baru diteruskan ke nomor handphone tujuan. Konsumen dapat mengetahui status dari pesan. Jika handphone tujuan akan mengirimkan pesan konfirmasi ke SMSC yang menyatakan bahwa telah diterima, kemudian SMSC mengirim kembali status tersebut kepada handphone pengirim. Jika handphone mati atau tidak aktif, pesan yang akan dikirim akan disimpan pada SMSC sampai period validity (batas waktu pengiriman) terpenuhi. Period validity terlewati maka pesan yang akan dikirim akan dihapus dari SMSC dan SMSC akan mengirimkan informasi ke nomor pengirim bahwa SMS yang dikirim belum atau gagal diterima.

\section{B. Pembahasan}

a. Pengujian Sistem

Pengujian dan Analisa Mikrokontroler Atmega16 berfungsi sebagai pusat pengolahan data dan pengendali bagi perangkat lain seperti relay, dan modul GSM Wavecom Pada saat handphone mengirim SMS maka SMS tersebut akan diterima oleh modem GSM Wavecom kemudian akan diolah oleh mikrokontroler ATmega16. Jika SMS sesuai dengan program yang telah tersimpan maka mikrokontroler akan menggerakan relay.

Pengujian dari sistem pendeteksi keamanan ruangan dilakukan pada beberapa aspek diantaranya:

a. mendeteksi Objek berkisar antara 1 meter - 5 meter.

b. Kecepatan pengiriman data

c. Jenis data yang dikirim berupa teks

Tabel 2. Percobaan pada manusia hewan dan benda pada jarak 1- 7 meter

\begin{tabular}{|l|l|c|c|c|c|}
\hline No & $\begin{array}{l}\text { Uji } \\
\text { coba }\end{array}$ & Manusia & Hewan & Benda & Jarak \\
\hline 1 & Uji 1 & $\checkmark$ & - & - & 1 \\
\hline 2 & Uji 2 & $\checkmark$ & - & - & 2 \\
\hline 3 & Uji 3 & $\checkmark$ & - & - & 3 \\
\hline 4 & Uji 4 & $\checkmark$ & - & - & 4 \\
\hline 5 & Uji 5 & $\checkmark$ & - & - & 5 \\
\hline 6 & Uji 6 & - & - & - & 6 \\
\hline 7 & Uji 7 & - & - & - & 7 \\
\hline
\end{tabular}

Pada percobaan pada jarak diatas 5 meter ini kita menemukan hasil yang berbeda dari hasil percobaan sebelumnya, hasil percobaan yang dilakukan semuanya tidak ada yang terdeteksi. Alasan nya karena jarak yang bisa dideteksi oleh sensor paling jauh pada jarak 5 meter dan hanya berfungsi pada manusia bukan pada hewan maupun benda. 
Jurnal Pseudocode, Volume V Nomor 2, September 2018, ISSN 2355-5920, e-ISSN 2655-1845 www.ejournal.unib.ac.id/index.php/pseudocode

Tabel 3. Data hasil pengujian dalam satuan detik

\begin{tabular}{|l|l|l|l|}
\hline No & Tanggal & Terdeteksi & $\begin{array}{l}\text { Waktu sms di } \\
\text { terima }\end{array}$ \\
\hline 1 & $02-08-17$ & $18: 31: 36$ & $18: 31: 43$ \\
\hline 2 & $02-08-17$ & $18: 33: 25$ & $18: 33: 33$ \\
\hline 3 & $02-08-17$ & $18: 35: 19$ & $18: 35: 29$ \\
\hline 4 & $04-08-17$ & $20: 21: 32$ & $20: 21: 43$ \\
\hline 5 & $04-08-17$ & $20: 35: 46$ & $20: 35: 57$ \\
\hline 6 & $04-08-17$ & $21: 05: 16$ & $21: 05: 27$ \\
\hline
\end{tabular}

Pengujian ini dilakukan untuk mengetahui berapa lama delay pengiriman pesan dari modem ke handpone pada saat sensor mendeteksi adanya gerakan manusia.

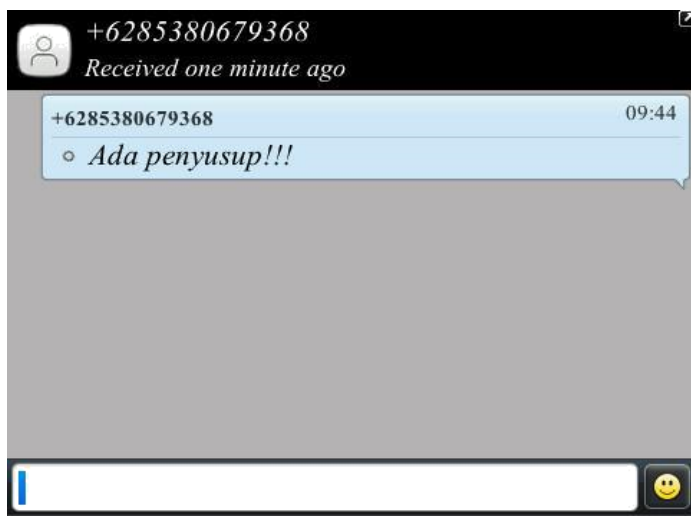

Gambar 16. Hasil pengiriman SMS dari Server

Pengujian alat digunakan pada satu ruangan yang kondisi dan tata letak telah disesuaikan dengan kebutuhan system. Percobaan dilakukan dengan menggunakan parameter jarak dan kualitas dari alat yang digunakan baik itu sensor, mikrokontroler, dan wireless modem. Penggunaan sensor merupakan hal yang utama yang wajib diuji pada alat ini, karena sensor merupakan alat pemantau utama. Pengujian pada sensor dilakukan dengan melibatkan parameter jarak dari benda yang akan dijadikan penghalang. Disini sensor hanya mampu memantau jarak deteksi 1 meter - 5 meter yang akan mengirim sinyal ke mikrokontroler dan hal diatas sudah dibuktikan pada tabel pengujian di atas.
Pengujian pada mikrokontroler yang bertugas menerima data logic dari sensor PIR telah dilakukan pengaktifan port dari wireless modem yang active low (aktif ketika menerima data logic “0”) jika sensor mengirim hasil pemantauan.

\section{b. Hasil Pengujian}

Dari percobaan yang dilakukan sebagai berikut:

1. Pengintegrasian alat antara modul mikrokontrol, sensor PIR dan wireless modem tlah berhasil dilakukan ditandi dengan bekerjanya alat sesuai program yang telah dibuat menggunakan bahasa Pemrograman Code Vision AVR

2. Sensitifitas darisensor PIR mengirim data hasil pengamatan kepaadmikrokontrolertelah terukur dengan delay rata-rata SMS 11.1 detik.

3. Sensor hanya mendeteksi suhu tubuh dari manusia , apabila ada benda bergerak yang lain atau makluk hidup yang lain seperti binatang maka sensor tidak mendeteksi karena adanya sensor PIR (Passive Infrared Receiver.

Pada umumnya sensor PIR ini memiliki jangkauan pembacaan efektif hingga 5 meter, dan sensor ini sangat efektif digunakan sebagai human detector.

\section{KESIMPULAN DAN SARAN}

\section{A. Kesimpulan}

Berdasarkan hasil pengujian yang telah dapat disimpulkan sebagai berikut:

1. pengintegrasian alat antara modul mikrokontrol, sensor PIR dan wireless modem tlah berhasil dilakukan ditandi dengan bekerjanya alat sesuai program yang telah dibuat menggunakan bahasa Pemrograman Code Vision AVR. 
Jurnal Pseudocode, Volume VI Nomor 2, September 2019, ISSN 2355-5920, e-ISSN 2655-1845 www.ejournal.unib.ac.id/index.php/pseudocode

2. Sensitifitas dari sensor PIR mengirim data hasil pengamatankepadmikrokontrolertelah terukur dengan delay rata-rata SMS 15.1 detik dan jangkauan sensor terhadap objekyang bisa terdeteksi paling jauh dalam jarak 1 sampai 3 meter.

3. Sensor hanya mendetksi suhu tubuh dari manusia , apabila ada benda bergerak yang lain aatau makluk hidup yanglain seperti binatang maka sensor tidak mendeteksi karena adanya sensor PIR (Passive Infrared Receiver).

4. Pada umumnya sensor PIR ini memiliki jangkauan pembacaan efektif hingga 5 meter, dan sensor ini sangat efektif digunakan sebagai human detector.

\section{B. Saran}

Beberapa saran yang perlu diperhatikan untuk pengembangan selanjutnya antara lain :

1. Sistem pendeteksi keamanan ruangan dapat dibuat lebih banyak untuk menjaga rumah agar selalu dalam keadaan aman.

2. Sistem pendeteksi keaamanan ruangan ini juga dapat disempurnakan dengan penambahan kamera (CCTV) / Media Center.

\section{REFERENSI}

[1] Sumard, 2017 “ Model Control Lampu Kamar Mandi Menggunakan Sensor Passive Infrared Receiver Berbasis Arduino Uno ", ISSN : 2580-1503, METIK Jurnal Vol. 1 No. 2

[2] Febriko Anip, 2016' Perancangan Sistem Pengamanan Ruang Harvard Mikrokontroler (arduino) dengan Metode Motion Detection, Teknologi dan Sistem Informasi UNIVRAB, ISSN : 2477-2062, VOL. 1 No. 1
[3] Ahadiah Siti , Muharnis , Agustiawan, 2017 “ Implementasi Sensor Pir Pada Peralatan Elektronik Berbasis Microcontroller, Jurnal Inovtek Polbeng “, EISSN: 2580-2798, Vol. 7 No. 1

[4] Gagat Mughni Pradipta, Nida Nabilah, Hannif Izzatul Islam, Dendy Handy Saputra, Sofyan Said, Ade Kurniawan, Heriyanto Syafutra, Shelvie Nidya Neiman, Irzaman, 2016

“ Pembuatan Prototipe Sistem Keamanan Laboratorium Berbasis Arduino Mega “, Prosiding Seminar Nasional Fisika (E-Journal) SNF2016, e-ISSN: 2476-9398, Vol. V

[5] Rini Herlina Dakhi, 2017 “ Sistem Pemantau Ruang Jarak Jauh Menggunakan Sensor PIR (Passive Infrared) Berbasis Atmega 8535 “ , Skripsi, Fakultas Matematika Dan Ilmu Pengetahuan Alam, Universitas Sumatera Utara.

[6] Ruri Hartika Zain, 2013 “ Sistem Keamanan Ruangan Menggunakan Sensor Passive Infra Red (Pir) Dilengkapi Kontrol Penerangan Pada Ruangan Berbasis Mikrokontroler Atmega8535 Dan Real Time Clock Ds1307 “, Jurnal Teknologi Informasi Dan Pendidikan, ISSN : 2086 - 4981, Vol. 6 No. 1.

[7] Sulistiyowati Istri, 2012 “ Perancangan dan Implementasi Aplikasi Berbasis SMS Gateway sebagai Media informasi Absensi Siswa di SMP Negeri 1 Tambak “ Jurnal Sain dan Teknologi Informasi, Vol 1 No. 2.

[8] Lubis Ridwan Muhammad, 2016 “ Sistem Layanan Antrian dengan SMP pada Unit Pelayanan Mahasiswa (Studi Kasus : AMIK Tunas Bangsa Pematang Siantar) ", Sinkron, Jurnal dan Penelitian Teknik Informatika Vpl. 1 No. 1.

[9] Sony Ericsson Mobile Communications, "AT Commands Online Reference", Diakses 27 Mei 2008 dari Sony Ericsson.

[10] Sumita Kasera, Nishit Narang, 2005 “ $3 G$ Mobile Networks, McGrow-Hill. Yew York. Vijay K.Garg “, Wireless Network Evolution, prentice hall.

[11] Wignjosoebroto, Sritomo, 2003” Ergonomi (Studi Gerak dan Waktu) “, Penerbit Guna Widya, Surabaya.

[12] Soltysik, R.. paging alarm systems for automotive security application, IEE colloquiumon vehicle security systems. 1993 pp. 3/1-3/2. 